\title{
Acrylamide in Food Products: A Review
}

\author{
Krishnakumar $\mathrm{T}^{1 *}$ and Visvanathan $\mathbf{R}^{2}$
}

${ }^{1}$ Department of Food and Agricultural Process Engineering, Tamil Nadu Agricultural University, Coimbatore, India

${ }^{2}$ Post Harvest Technology Centre, Tamil Nadu Agricultural University, Coimbatore, India

\begin{abstract}
Acrylamide or 2-propenamide an industrial chemical formed in some foods particularly starchy foods during heating process such as baking, frying and roasting. Acrylamide is proven to be carcinogenic in animals and a probable human carcinogen mainly formed in foods by the reaction of asparagine (free amino acid) with reducing sugars (glucose and fructose) as part of the Maillard reaction during heating under high temperature and low moisture conditions. The main aim of this review is to summarize the results of academic and industrial research on occurrence, dietary exposure, formation mechanism and mitigation measures of acrylamide in bakery, cereal and potato food products.
\end{abstract}

Keywords: Acrylamide; Asparagine; Maillard reaction; Bakery; Cereal; Potato products

\section{Introduction}

Acrylamide $\left(\mathrm{C}_{3} \mathrm{H}_{5} \mathrm{NO} ; 2\right.$-propenamide), is a colourless, non-volatile crystalline solid, soluble in water and has a molecular weight of 71.08 $\mathrm{kDa}[1,2]$. It is produced commercially by hydrolyzing acrylonitrile using nitrile hydrase and exists in two forms: monomer and polymer. It is used to produce polyacrylamide polymer, which find many uses as a coagulant in waste water treatment and clarifying drinking water, grouting agents for the construction of dam foundations and tunnels and as electrophoresis gels. In 1994, the International Agency for Research on Cancer (IARC) classified acrylamide as a potential carcinogen to humans (Group 2A) based on its carcinogenicity in rodents. This classification was endorsed by the WHO Consultation in 2002. The single (monomer) form of acrylamide, is recently discovered to be present in food, which is toxic to the nervous system. A carcinogen in rodents, and a suspected carcinogen in humans cause gene mutation and DNA damage [2,3-12]. It is probably always been present in cooked foods and cigarette smoke. However, the presence of acrylamide in foods was first reported by the Swedish National Food Administration (SNFA) in 2002. It is considered as the important heatinduced process contaminants formed mostly in potato, cereal and bakery products, respectively by the heat treatment.

\section{Occurrence and Dietary Intake}

People are exposed to different amounts of acrylamide mainly through the diet. Acrylamide occurrence in foods is being studied intensively since the original report of high levels of acrylamide found in food that are subjected to high temperature [6,13,14]. Acrylamide primarily found in plant based foods; heat treated starchy foods such as potato, cereal and bakery products contains high levels of acrylamide [6,13,15-19]. Acrylamide is not found in foods that are not fried or baked such as boiling or microwaving (Eriksson, 2005; Törnqvist, 2005) $[2,20]$ and found very low levels in animal based food products such as meat and fish. To date, there is no permissible limits have been set worldwide for acrylamide consumption in diet. To analyze the acrylamide presence in diet, different dietary exposure databases consist of different food groups have been prepared by the European Union's acrylamide monitoring database, the United States Food and Drug Administration's acrylamide survey data and the WHO's summary information and Global Health Trends database. Estimation of acrylamide occurrence in food commodities is a great concern in many countries. Moreover, the predictions of dietary acrylamide intake have been made for populations in many countries consist of different dietary records [21-33]. These studies found that the amount of acrylamide was extremely higher in fried potato products (such as French fries and potato chips) followed by cereals, crisp breads, biscuits and other bakery products. Concentration and dietary intake of food have significant variations, which depends upon cooking methods [21,34-42]. Factors such as difference in food composition, high temperature (more than $120^{\circ} \mathrm{C}$ ), and high carbohydrate, free asparagine, reducing sugars, $\mathrm{pH}$, water content, ammonium bicarbonate and high concentration of competing amino acids could be the sources for variation in acrylamide level [43-47]. Dietary acrylamide intake may increase the risks of kidney and breast cancer $[48,49]$. The daily intake of acrylamide in human diets was estimated to be 0.3 to $0.8 \mu \mathrm{g}$ per $\mathrm{kg}$ body weight [42]. At normal conditions, the average total daily intake of acrylamide is about $0.85 \mu \mathrm{g}$ per kg body weight [50]. The total macro and micro nutrient composition of the diet is mainly obtained from acrylamide containing foods [51]. Foods that are contributing most dietary intake of acrylamide differ from country to country [52]. Foods with high acrylamide levels contribute to $38 \%$ of daily calories, $36 \%$ of fibre and greater than $25 \%$ of micronutrients [53].Generally, darker the colour of food product, higher the acrylamide content. Acrylamide formation increases drastically towards the end of the frying process [54]. The amounts of acrylamide in different food and food product groups are summarized in Table 1.

\section{Mechanisms of Formation}

Acrylamide is not a substance that is added to food, but it is formed in food during heat processing. Research indicates that heating of food could be an important source of acrylamide formation. Acrylamide formed in a wide variety of foods, particularly carbohydrate (reducing sugars) rich foods cooked at above $120^{\circ} \mathrm{C}$ upon frying, baking and roasting [55-57]. However, acrylamide formation in potato fries taken place at below $120^{\circ} \mathrm{C}$ at low moisture content and prolonged heating

*Corresponding author: Krishnakumar T, Department of Food and Agricultural Process Engineering, Tamil Nadu Agricultural University, Coimbatore, India - 641 003, Tel: 91-8903938288; E-mail: krishnakumar_meag@yahoo.co.in

Received April 16, 2014; Accepted June 27, 2014; Published July 23, 2014

Citation: Krishnakumar T, Visvanathan R (2014) Acrylamide in Food Products: A Review. J Food Process Technol 5: 344. doi:10.4172/2157-7110.1000344

Copyright: @ 2014 Krishnakumar T, et al. This is an open-access article distributed under the terms of the Creative Commons Attribution License, which permits unrestricted use, distribution, and reproduction in any medium, provided the original author and source are credited. 


\begin{tabular}{|c|c|}
\hline Product/ Product group & Acrylamide range $\left(\mu \mathrm{g} \mathrm{kg}^{-1}\right)$ \\
\hline Bakery products and biscuits & $18-3324$ \\
\hline Breads & $<10-3200$ \\
\hline Bread (toast) & $25-1430$ \\
\hline Breakfast cereals & $<10-1649$ \\
\hline Chocolate products & $<2-826$ \\
\hline Coffee substitute & $80-5399$ \\
\hline Dairy products & $<10-130$ \\
\hline French fries/chips & $59-5200$ \\
\hline Meats & $<10-116$ \\
\hline Potatoes (raw) & $<10-<50$ \\
\hline Potato chips/crisps & $117-4215$ \\
\hline Roasted coffee & $45-9359$ \\
\hline
\end{tabular}

Table 1: Amounts of acrylamide in different foods and food product groups. Adapted from Peterson [150].

conditions [58]. The basic formation routes of acrylamide in foods in shown in Figure 1. Acrylamide formation follows different routes in conjunction with the Maillard reactions system in food products, where the asparagine route is the major one for the formation of acrylamide [2].

\section{Formation via Asparagine Route}

The major pathway leading for acrylamide formation in foods is a part of the Maillard reaction with free amino acid (asparagine) and reducing sugars (mainly glucose and fructose) [59-66] (Figure 2). Maillard reaction is a non-enzymatic browning reaction occurring in foods during baking or frying. This happens at proper combination of carbohydrates, lipids and proteins for desirable colour, flavour and aroma [61,67]. Asparagine, is the free amino acid present in potatoes in high level (93.6 mg per $100 \mathrm{~g}$ ) [68], needs carbohydrates to form acrylamide [69]. The potential of acrylamide formation is strongly related to glucose and fructose content [70,71]. Free asparagine concentration to be the main determinant of acrylamide formation in rye varieties [72] and in cooked flours and doughs (mainly rye and wheat) [73]. Research has shown that the reducing sugars are the major limiting factors in potatoes [74-77], while asparagine (mainly in the cereal bran) is the major limiting factors in cereal products [78-81].

\section{Formation via Alternative Routes}

Although formation of acrylamide in foods has its major routes through asparagine and reducing sugars, several other formation routes suggested via. Acrolein and ammonia (Figure 3). In the absence of asparagine, acrolein and ammonia to play a role in lipid rich foods to form acrylamide. It is known that acrolein and acrylic acid are produced by degradation of lipids (triglycerides) in subject to high temperature $[83,84]$. Degradation of amino acids with ammonia can give rise to acrylamide formation by thermal decomposition [85-89]. Amino acids such as glutamine, cysteine and aspartic acid have also been found to produce low amounts of acrylamide [90,91]. However, stated that this mechanism might be irrelevant for acrylamide formation in foods [74,79].

\section{Mitigation Strategies for Acrylamide}

Significant efforts have been undertaken in order to develop appropriate strategies that reduce acrylamide in foods. Reducing acrylamide content in foods at household and industrial level can help the public not only from food hazards but also to create perception about the food safety. A number of mitigation strategies have been focused so far regarding acrylamide formation at different stages of food production are discussed in the following sections.

\section{Effect of Raw Materials}

The influence of variety, harvest year, fertilization and storage conditions on acrylamide formation have been studied in potato products [92-97] and also in cereal products [98-102]. The composition of potatoes vary with variety to variety $[103,104]$ and it relatively contains high amounts of reducing sugars, which is the major limiting factor in potato products for acrylamide formation of the positive influence of cereal varieties on precursors and acrylamide contents. Therefore, controlling reducing sugars and asparagine may be a better option to reduce acrylamide in potato and cereal products respectively (David et al., 2012) [56]. Potato varieties with low concentrations of reducing sugars can be an effective way to reduce acrylamide concentration $[77,104,105]$.

Climatic condition such as harvest year has a significant impact on asparagine and reducing sugars in potatoes. The asparagine content was significantly lower in all the samples from the 2004 harvest as compared to 2003 [106]. This study concluded that an extremely hot summer will result in lower acrylamide generation. Fertilization is considered to be a key factor in crop production. A decrease in nitrogen fertilization enhanced reducing sugars concentrations, resulting in an increase of acrylamide formation in potato products [107]; whereas

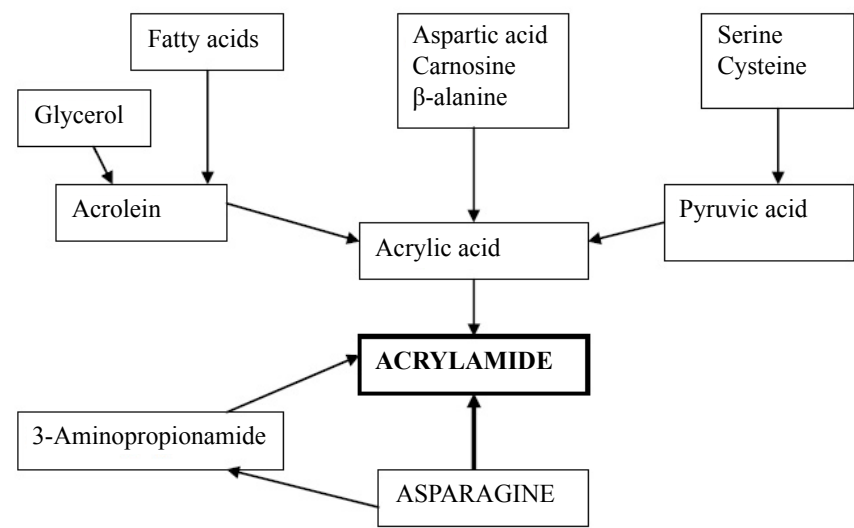

Figure 1: The basic formation routes of acrylamide in foods [2].

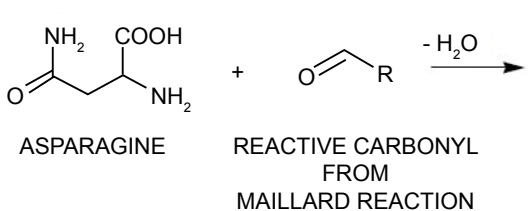<smiles>[R]C(=O)C=NC(CC(N)=O)C(=O)O</smiles>
MAILLARD REACTION<smiles>[R]C(=O)/C=N/CC(C(N)=O)C(C)O</smiles><smiles>[R]C(=O)CN=CCC(N)=O</smiles>

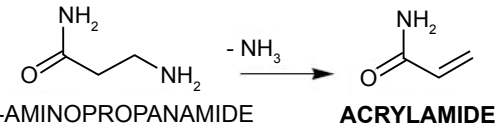

$\mathrm{NH}_{2}$<smiles>NC(=O)CC=O</smiles>
STRECKER

Figure 2: Proposed mechanism for formation of the acrylamide in heat treated foods [164]. 


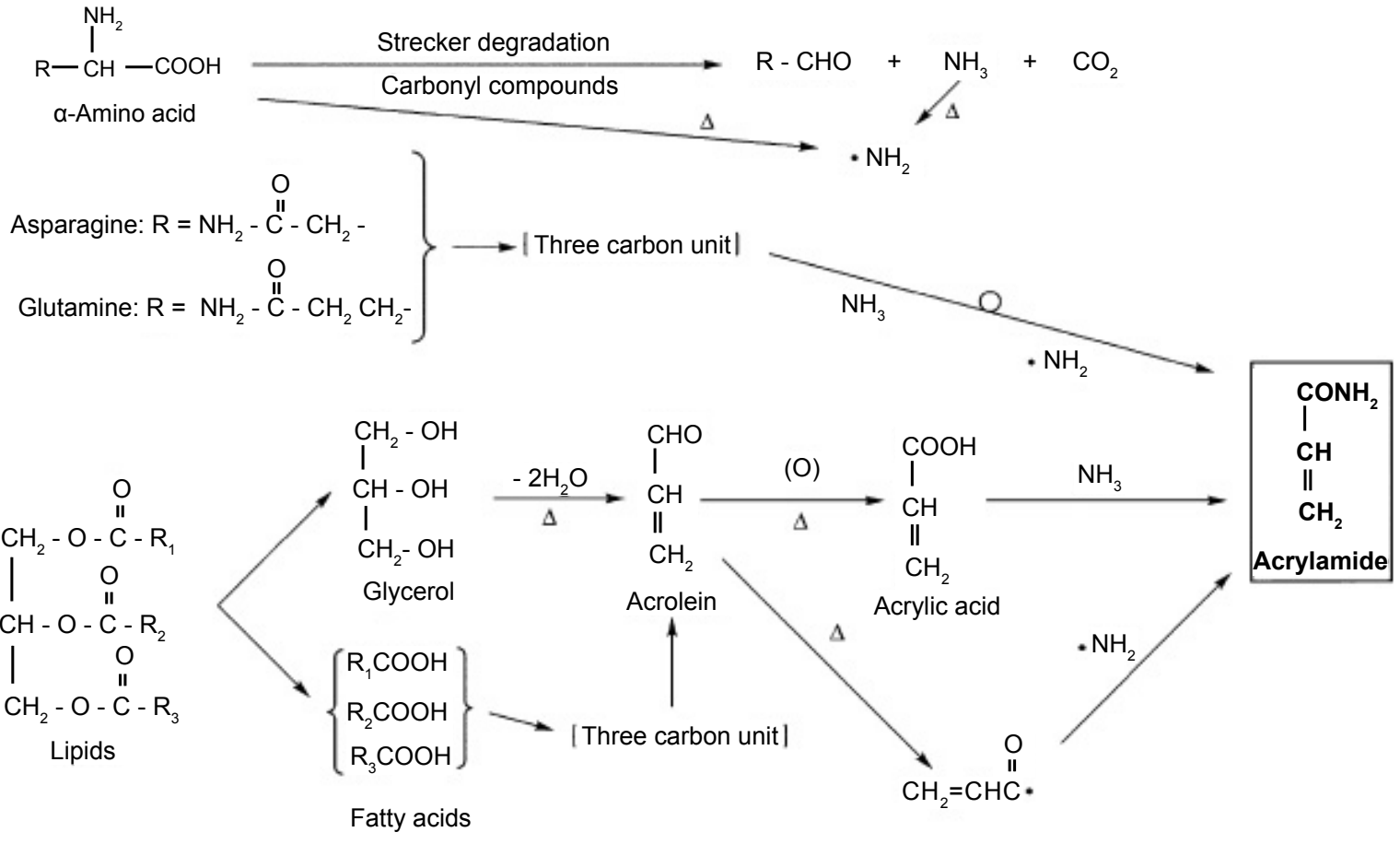

Triolein: $\mathrm{R}_{1}, \mathrm{R}_{2}, \mathrm{R}_{3}=\left(\mathrm{CH}_{2}\right)_{7} \mathrm{CH}=\mathrm{CH}\left(\mathrm{CH}_{2}\right)_{7} \mathrm{CH}_{3}$

Figure 3: Hypothesized formation mechanism of acrylamide from an amino acid and a lipid.

inverse effects have been noticed for bakery products. However, reducing sugars in wheat were not affected by fertilization. Generally, potato tubers are stored for several months in order to meet the supply throughout the year. Cold temperatures and senescent sweetening are the main causes of sugar accumulation in potatoes during storage [108]. Higher temperature storage (more than $8^{\circ} \mathrm{C}$ ), which results senescent sweetening is also related to sprout formation in potatoes [79]. Storing potatoes at low temperature (below $8^{\circ} \mathrm{C}$ ) found to be an effective technique/tool to inhibit sprouting [108]; temperature below $4-6^{\circ} \mathrm{C}$ has a major effect on reducing sugar accumulation [109-111]. However, reducing sugars in potatoes are not significantly varied when potatoes are stored at $8^{\circ} \mathrm{C}$ [112-115] and no changes are found in asparagine contents in potatoes stored at different temperature and time [114-116]. In order to reduce acrylamide formation, potato tubers should be ideally stored at $8^{\circ} \mathrm{C}[117]$.

\section{Effect of Additives}

Asparaginase, an enzyme that converts precursor (asparagine) into ammonia and aspartic acid, can reduce acrylamide formation in foods [117-121]. It is commercially produced from Aspergillus niger (DSM's Preventase) or Aspergillus oryzae (Novozyme's Acrylaway) and found its most applications in potato and cereal products. Though it is a promising strategy for acrylamide reduction, it is rather expansive compared with other strategies.

The addition of amino acids or protein rich substances reduces the acrylamide content in foods [122,123]. Amino acids such as glycine, cysteine, methionine, glutathione and lysine on acrylamide formation and its elimination kinetics was assessed in several studies [124134]. Formation of acrylamide decreased by $50 \%$ when cysteine and methionine were added to cracker [135] and potato dough [136]. On the contrary, Flückiger and Salih [137] studied the effect of cysteine on acrylamide formation in crisp bread and found that no such effects.

Addition of antioxidants has been found to influence the Maillard reaction, which results in acrylamide formation [138145]. Antioxidants present in the rosemary extracts, bamboo leaves and green tea extract $[146,147]$ could effectively reduce acrylamide presence in different heated foods. The exact mechanism on acrylamide formation is not yet understood, however it is proposed that it could interact with active aldehydes and block the oxidation of acrolein to a certain extent $[148,149]$. Moreover, most of these studies are based on in vitro or small scale conditions and ultimately may not provide the similar results on commercial or industrial conditions.

Mono and divalent cations $\left(\mathrm{Na}^{+}\right.$and $\mathrm{Ca}^{2+}$ or $\left.\mathrm{Mg}^{2+}\right)$ added to the dough showed a remarkable effect on acrylamide reduction [150]. In addition, polyvalent cations also capable to reduce acrylamide formation during heating [151]. These ions could interact with asparagine so that prevent the Schiff base intermediate formation and thus acrylamide generation [151-155].

A significant effect of $\mathrm{NaCl}$ on acrylamide reduction via polymerization was reported by several studies. However, the acrylamide content increased at higher $\mathrm{NaCl}$ levels, which was attributed to an inhibition of yeast growth by the salt [156]. Acrylamide formation in potato strips reduced by hydrocolloid coatings when alginic acid and pectin were used as coating agents [157], whereas carob gum, carrageenan, hydroxypropyl distarch phosphate and xanthan gum stimulated acrylamide formation.

\section{Effect of Processing Conditions}

Most of the strategies proposed to reduce the acrylamide are 
focused on the processing stage. The important factors that influence the process of acrylamide formation are: heating temperature and time, blanching and frying [116]. Several studies were conducted on the effects of baking temperature and time combination during baking and found strong correlation between baking temperature and time and acrylamide formation [158-162]. However, the prolonged baking temperature and time combination $\left(260^{\circ} \mathrm{C}, 20 \mathrm{~min}\right)$ decreased the acrylamide content in foods. Biedermann and Grob found that acrylamide could also be formed at below $100^{\circ} \mathrm{C}$. Compared with conventional baking conditions, optimized conditions such as temperature and relative humidity profile resulted in a 50\% reduction of acrylamide formation. Conduction and radiation heat transfer are more effective in acrylamide reduction than convection baking ovens. Moreover, the combination of conventional and dielectric (microwave) heating found to be suitable for reduction of acrylamide in bakery products. Baking at high relative humidity proved to be effective for reducing acrylamide in bakery products $[163,164]$. This can be achieved not only by reducing the temperature, but also by using steam as heating medium during the final part of baking [164]. The reference baking temperature and time considered were $200^{\circ} \mathrm{C}$ for 20 min. Acrylamide formation mostly occurs in the outer crust than in the inner crust of bread, while only trace amount appears in the crumb $[165,166]$.

Blanching is an important unit operation in the prediction of French fries production. This reduces acrylamide formation mainly by leaching the precursors (reducing sugars) prior to frying [167-172]. Blanching conditions (temperature and time) can be varied in order to maintain the final product specifications constant. Blanching at $70^{\circ} \mathrm{C}$ for 10 to $15 \mathrm{~min}$, reduced acrylamide formation of $65 \%$ and $96 \%$ for French fries and potato chips, respectively. Frying is used in food processing both at industrial and home levels. Acrylamide formation is correlated to colour development, which occurs in Maillard reaction during heating process, mostly at the end of the frying process $[173,174]$. Intensive frying conditions (temperature and time) lead to darker fries and higher acrylamide formation. Thus, two factors such as frying temperature (should not exceed $170-175^{\circ} \mathrm{C}$ ) and time to be considered as important for acrylamide reduction. Frying under low pressure conditions using vacuum fryer results in higher acrylamide reduction [175].

\section{Effect of PH, Water Activity and Fermentation}

Maillard reaction has strong influence on $\mathrm{pH}$. It is known that high $\mathrm{pH}$ affect nutrients in foods (Eriksson, 2005). Researchers showed that the reduced $\mathrm{pH}$ drastically reduces acrylamide content during frying and baking $[176,177]$. Any acid treatment reduces the $\mathrm{pH}$ of foods and results in formation of Maillard associated substances. Addition of different acids decreased the amount of acrylamide in bakery products such as corn chips, semi-finished biscuits and cracker models [177,178]. Reduced $\mathrm{pH}$ levels results in Maillard reactions, accompanied by reduced acrylamide formation $[179,180]$. Water activity in food plays a major role in reducing acrylamide formation. Acrylamide forms in food only when the water activity is below 0.8 , whereas the acrylamide formation is high at water activity of 0.4 and below $[181,182]$. However, the removal of acrylamide from heated foods such as biscuits and potato chips increases with the increase of water activity. The percentage of acrylamide removal from cookies and potato chips having different water activity values is presented in Table 2. Fermentation controls the rate of acrylamide formation in food by maintaining precursor composition and $\mathrm{pH}$. Prolonged fermentation time (at least an hour) was found to be suitable for acrylamide reduction in bread and fried

\begin{tabular}{|c|c|c|}
\hline Foods & Water activity & Acrylamide removed (\%) \\
\hline \multirow{3}{*}{ Cookies } & 0.12 & 12 \\
\cline { 2 - 3 } & 0.53 & 27 \\
\cline { 2 - 3 } & 0.83 & 32 \\
\hline \multirow{3}{*}{ Potato chips } & 0.26 & 0 \\
\cline { 2 - 3 } & 0.64 & 0 \\
\cline { 2 - 3 } & 0.74 & 4 \\
\hline & 0.83 & 11 \\
\hline
\end{tabular}

Table 2: Percentage of acrylamide removal from cookies and potato chips having different water activity values, subjected to treatment at $6.67 \mathrm{~Pa}$ and $60^{\circ} \mathrm{C}$ for $1 \mathrm{~h}$ [165].

potato products [183-186]. Combined lactic acid fermentation with blanching found suitable for higher acrylamide reduction in potato products [187].

\section{Conclusions}

The major limiting factors responsible for the formation of acrylamide in potato and cereal products are reducing sugars (glucose and fructose) and free asparagines (amino acids) respectively. For commercial production of potato products, select cultivars with low levels of reducing sugars taking into account seasonal and regional variability for high temperature processes such as frying and baking. Avoid using potato tubers stored below $6^{\circ} \mathrm{C}$ and maintain ideal storage temperature of about $8^{\circ} \mathrm{C}$. However, retailers and consumers are unaware of the selection of cultivar and safe storage temperature. Therefore the advantages of these conditions have to be well informed to retailers and consumers through campaign by mass media and concerned food safety authority. Blanching in water followed by frying at controlled temperature-time combinations might be a better option to reduce the acrylamide formation in potato products. Use of additives such as amino acids, asparaginase enzyme, cations and antioxidants are reported effective for acrylamide reduction in bakery and cereal products. Nevertheless, the additives should not alter the quality and consumer acceptability of food products. Yeast fermentation is a promising technology, which will reduce the free asparagine precursor content in cereal products such as wheat bread. Combination of yeast fermentation and blanching will substantially reduce the acrylamide content in potato products. However, the strategy or approach developed for potato products are not applicable /transferable to other food products such as bakery and cereal products. A strong positive correlation exists between baking temperature and time and formation of acrylamide; whilst the use of flour with low asparagine content might decrease the content of acrylamide in bakery products. By introducing steam in conventional or traditional baking system, it is possible to reduce the acrylamide content in baked products. The strategies developed so far to mitigate acrylamide formation studied on lab conditions, which may not be suitable for commercial process. Therefore further work is necessary to explore different possibilities studied in the laboratories on industrial conditions. Reducing acrylamide in food products while protecting other quality aspects and reducing dietary acrylamide exposure still remains a major challenge.

\section{References}

1. Ashoor SH, Zent JB (1984) Maillard browning of common amino acids and sugars. Journal of Food Science 49: 1206-1207.

2. Eriksson $S$ (2005) Acrylamide in food products: Identification, formation and analytical methodology. Doctoral thesis, Department of Environmental Chemistry, Stockholm University, Sweden.

3. IARC (1994) Acrylamide. IARC monographs on the evaluation of carcinogenic risks to humans, some industrial chemicals 60: 387-433. 
4. Friedman MA, Dulak LH, Steham MA (1995) A Lifetime Oncogenicity Study in Rats with Acrylamide. Toxicol Sci 27: 95-105

5. Rosen J, Hellenas KE (2002) Analysis of acrylamide in cooked foods by liquid chromatography tandem mass spectrometry. Analyst 127: 880-882.

6. Tareke E, Rydberg P, Karlsson P, Eriksson S, Törnqvist M (2002) Analysis of acrylamide, a carcinogen formed in heated foodstuffs. Journal of Agricultural and Food Chemistry 50: 4998-5006.

7. Törnqvist M, Fred C, Haglund J (2002) Protein adducts: quantitative and qualitative aspects of their formation, analysis and applications. J Chromat B 778: 279-308.

8. Rice JM (2005) Carcinogenicity of acrylamide. Mutation Research 580: 3-20

9. Manson J, Brabec MJ, Buelke SJ, Carlson GP, Chapin RE, et al. (2005) NTPCERHR Expert panel report on the reproductive and developmental toxicity of acrylamide. Birth Defects Research (Part B) 74: 17-113.

10. JECFA (2006) Evaluation of certain food contaminants. 64th report of the join FAO/WHO expert committee on food additives. WHO Technical Report Series 930: 8-26.

11. Shipp A, Lawrence G, Gentry R, McDonald T, Bartow H, et al. (2006) Acrylamide: Review of toxicity data and dose-response analyses for cance and non-cancer effects. Critical Reviews in Toxicology 36: 481-608.

12. Mojska H, Gielecinska I, Szponar L, Oltarzewski M (2010) Estimation of the dietary acrylamide exposure of the Polish population. Food and Chemical Toxicology 48: 2090-2096.

13. SNFA (2002) Swedish National Food Administration: Analysis of acrylamide in food.

14. Weisshaar R, Gutsche B (2002) Formation of acrylamide in heated potato products- Model experiments pointing to asparagine as precursor. Deutsche Lebensm Rundschau 98: 397-400.

15. Svensson K, Abramsson L, Becker W, Glynn A, Hellenas KE, et al. (2003) Dietary intake of acrylamide in Sweden. Journal of Food Chemistry and Toxicology 41: 1581-1586.

16. Surdyk N, Rosen J, Andersson R, Aman P (2004) Effects of asparagine fructose, and baking conditions on acrylamide content in yeast leavened wheat bread. J Agric Food Chem 52: 2047-2051.

17. EFSA (2009) Scientific report of EFSA prepared by data collection and exposure unit (DATEX) on "Monitoring of acrylamide levels in food". The EFSA Scientific Report 285: 1-26.

18. Borda T, Alexe P (2011) Acrylamide levels in food. Romanian Journal of Food Science 1: 3-15

19. Riboldi BP, Vinhas ÁM, Moreira JD (2014) Risks of dietary acrylamide exposure: A systematic review. Food chemistry 157: 310-322.

20. Törnqvist M (2005) Acrylamide in food: The discovery and its implications. Chemistry and safety of acrylamide in food $561: 1-19$.

21. Konings EJM, Baars AJ, van Klaveren JD, Spanjer MC, Rensen PM, et al (2003) Acrylamide exposure from foods of the Dutch population and an assessment of the consequent risks. Food and Chemical Toxicology 41: 15691579.

22. Hilbig A, Freidank N, Kersting M, Wilhelm M, Wittsiepe J (2004) Estimation of the dietary intake of acrylamide by German infants, children and adolescents as calculated from dietary records and available data on acrylamide levels in food groups. International Journal of Hygiene and Environmental Health 207: 463-471.

23. Boon PE, De Mul A, Van der Voet H, Van Donkersgoed G, Brette M, et al. (2005) Calculation of dietary exposure to acrylamide. Mutation Research 580: $143-155$

24. Dybing E, Farmer PB, Andersen M, Fennell TR, et al. (2005) Human exposure and internal dose assessments of acrylamide in food. Food and Chemical Toxicology 43: 365-410.

25. Fohgelberg P, Rosén J, Hellenäs KE, Abramsson-Zetterberg L (2005) The acrylamide intake via some common baby food for children in Sweden during their first year of life- an improved method for analysis of acrylamide. Food and Chemical Toxicology 43: 951-959.

26. Matthys C, Bilau M, Govaert Y, Moons E, De Henauw S, et al. (2005). Risk assessment of dietary acrylamide intake in Flemish adolescents. Food and Chemical Toxicology 43: 271-278

27. Hilbig A, Kersting M (2006) Dietary acrylamide exposure, time trends and the intake of relevant foods in children and adolescents between 1998 and 2004: results of the DONALD study. Journal fǘrVerbraucherschutz und Lebensmittelsicherheit 1: 8-10.

28. Sommerfeld C, Dehne L (2006) Vergleich der Acrylamidaufnahmeü berdie Nahrungbei Jugendlichen auf der Basis von Acrylamidgehaltenvon Januar 2003 und Oktober 2005. Journal für Verbraucherschutzund Lebensmittelsicherheit 1 : 285-289.

29. Mestdagh F, Maertens J, De Wilde T, Cucu T, Delporte K, et al. (2007) Chemica pre-treatments of potato products: mechanisms of acrylamide mitigation and effects on the sensorial quality. Presented at 234th ACS National Meet, Boston, MA

30. Boroushaki MT, Nikkhah E, Kazemi A, Oskooei M, Raters M (2010) Determination of acrylamide level in popular Iranian brands of potato and corn products. Food Chem Toxicol 48: 2581-2584.

31. Claeys W, Baert K, Mestdagh F, Vercammen J, Daenens P, et al. (2010) Assessment of the acrylamide intake of the Belgian population and the effect of mitigation strategies. Food Additives and Contaminants: Part A. Chemistry Analysis Control Exposure and Risk Assessment 27: 1199-1207.

32. FAO/WHO (2011) Joint FAO/WHO Expert Committee on Food Additives: Evaluation of certain contaminants in food report from 72nd meeting (Rep. No. WHO technical report series; No. 959).

33. Pedreschi F, Mariotti MS, Granby K (2014) Current issues in dietary acrylamide: formation, mitigation and risk assessment. Journal of the Science of Food and Agriculture 94: 9-20

34. Dybing E, Sanner T (2003) Risk assessment of acrylamide in foods Toxicological Sciences 75: 7-15.

35. Croft $M$, Tong $P$, Fuentes $D$, Hambridge $T$ (2004) Australian survey of acrylamide in carbohydrate-based foods. Food Additives and Contaminants 21: 721-736.

36. EFSA (2011) Scientific Report of EFSA - Results on acrylamide levels in food from monitoring years 2007-2009 and exposure assessment. EFSA Journal.

37. Palazoğlu TK, Savran D, Gökmen V (2010) Effect of cooking method (Baking Compared with Frying) on acrylamide level of potato chips. J Food Sci 75 : E25-E29.

38. FDA (US Food and Drug Administration) (2002) Exploratory Data on Acrylamide in Food. US Dept. of Health and Human Services, Centre for Food Safety and Nutrition.

39. Medeiros VR, Mestdagh F, Van PC, Kerkaert B, De Muer N, et al. (2011) Implementation of acrylamide mitigation strategies on industrial production of French fries: Challenges and pitfalls. Journal of Agricultural and Food Chemistry 59: 898-906.

40. Capuano E, Fogliano V (2011) Acrylamide and 5-hydroxymethylfurfural (HMF) A review on metabolism, toxicity, occurrence in food and mitigation strategies. LWT-Food Science and Technology 44: 793-810.

41. Chuda Y, Ono H, Yada H, Ohara TA, Matsuura EC, et al. (2003) Effects of physiological changes in potato tubers (Solanum tuberosum L.) after low temperature storage on the level of acrylamide formed in potato chips. Bioscience, Biotechnology and Biochemistry 67: 1188-1190.

42. World Health Organization (WHO) (2002) FAO/WHO Consultations on the health implications of acrylamide in foods. Summary report of a meeting held in Geneva.

43. Matthäus B, Haase NU, Vosmann K (2004) Factors affecting the concentration of acrylamide during deep-fat frying of potatoes. European Journal of Lipid Science and Technology 106: 793-801.

44. Taubert D, Harlfinger S, Henkes L, Berkels R, Schomig E (2004) Influence of processing parameters on acrylamide formation during frying of potatoes. Agric Food Chem 52: 2735-2739.

45. Deryck DP (2007) Acrylamide in fried, baked or roasted foods may increase risk of cancer in susceptible individuals. Internet Journal of Food Safety 9: 14-16.

46. Mustafa A, Kamal EA, Peterson EV, Andersson R, Åman P (2008) Effect of extraction $\mathrm{pH}$ on acrylamide content in fresh and stored rye crisp bread. J Food Comp Anal 21: 351-355. 
47. Medeiros VR, Mestdagh F, De Meulenaer B (2012) Acrylamide formation in fried potato products - Present and future, a critical review on mitigation strategies. Food Chemistry 133: 1138-1154.

48. Olesen PT, Olsen A, Frandsen H, Frederiksen K, Overvad K, et al.(2008) Acrylamide exposure and incidence of breast cancer among postmenopausal women in the Danish Diet, Cancer and Health Study. Int J Cancer 122: 20942100.

49. Hogervorst JG, Schouten LJ, Konings EJ, Goldbohm RA, van den Brandt PA (2008) Dietary acrylamide intake and the risk of renal cell, bladder, and prostate cancer. Am J Clin Nutr 87: 1428-1438

50. Schettgen T, Drexler H, Angerer J (2002) Acrylamide in the general population-A daily intake estimation. Umweltmedizin in Forschung und Praxis 7: 331-336.

51. Wilson K, Rimm E, Thompson K, Mucci L (2006) Dietary acrylamide and cancer risk in humans-A review. Journal fürVerbraucherschutz undLebensmittelsicherheit 1: 19-27.

52. Medeiros VR, Mestdagh F, De Meulenaer B (2012) Acrylamide formation in fried potato products-Present and future, a critical review on mitigation strategies. Food Chemistry 133: 1138-1154.

53. Petersen BJ, Tran N (2005) Chemistry and Safety of Acrylamide in Food, Advances in Experimental Medicine and Biology 561: 63-76.

54. Xu Y, Cui B, Ran R, (2014) Risk assessment, formation, and mitigation of dietary acrylamide: current status and future prospects. Food and Chemical Toxicology 69: 1-12.

55. Becalski A, Lau BPY, Lewis D, Seaman SW (2003) Acrylamide in foods: occurrence, sources, and modeling. J Agric Food Chem 51: 802-808.

56. David RL, James RC, Richard HS (2012) Acrylamide in foods: A review of the science and future considerations. Annual Review Food Sci. Technol 3: 15-35.

57. De Meulenaer B, De Wilde T, Mestdagh F, Govaert Y, Ooghe W, et al. (2008) Comparison of potato varieties between seasons and their potential for acrylamide formation. Journal of the Science of Food and Agriculture 88: 313318.

58. Gökmen V, Senyuva HZ (2006a) A simplified approach for the kinetic characterization of acrylamide formation in fructose-asparagine model system. Food Additives and Contaminants 23: 348-354

59. Biedermann M, Grob K (2003) Model studies on acrylamide formation in potato wheat flour and corn starch, ways to reduce acrylamide contents in bakery ware. MitteilungenausLebensmitteluntersuchung und Hygiene 94: 406-422.

60. Stadler RH, Blank I, Varga N, Robert F, Hau J, et al. (2002) Acrylamide from Maillard reaction products. Nature 419: 449-450

61. Coughlin JR (2003) Acrylamide: What we have learned so far. Food Technology.

62. Friedman M (2003) Chemistry, biochemistry, and safety of acrylamide-A review. Journal of Agricultural and Food Chemistry 51: 4504-4526.

63. Zyzak DV, Sanders RA, Stojanovic M, Tallmadge DH, Eberhardt BL, et al (2003) Acrylamide formation mechanism in heated foods. Journal of Agricultural and Food Chemistry 51: 4782-4787.

64. Yaylayan VA, Wnorowski A, Locas CP (2003) Why asparagine needs carbohydrates to generate acrylamide. J Agric Food Chem 51: 1753-1757.

65. Yaylayan V, Stadler R (2005) Acrylamide formation in food: a mechanistic perspective. Journal of AOAC International 88: 262-267.

66. Fishelier K, Hartmann A, Fiscalini A, Grob K (2005) Higher acrylamide contents in French fries prepared from "fresh" prefabricates. European Food Research of Technology 221: 376-381.

67. Tareke E, Rydberg P, Karlsson P, Eriksson S, Törnqvist M (2000) Acrylamide: a cooking carcinogen? Chem Res- Toxicol 13: 517-522.

68. Martin FL, Ames JM (2001) Formation of strecker aldehydes and pyrazines in a fried potato model system. Journal of Agricultural and Food Chemistry 49 3885-3892.

69. Pedreschi F, León J, Mery D, Moyano P, Pedreschi R, et al. (2007) Colour development and acrylamide content of pre dried potato chips. Journal of Food Engineering 79: 786-793.

70. Biedermann M, Biedermann BS, Noti A, Grob K (2002) Methods for determining the potential of acrylamide formation and its elimination in raw materials for food preparation, such as potatoes. Mitteilungenaus Lebensmitteluntersuchung und Hygiene 93: 653-667.

71. Pedreschi F, Kaack K, Granby K (2006) Acrylamide content and colour development in fried potato strips. Food Research International 39: 40-46.

72. Curtis TY, Powers SJ, Balagiannis D, Elmore JS, Mottram DS, et al. (2010) Free amino acids and sugars in rye grain: Implications for acrylamide formation. Journal of Agricultural and Food Chemistry 58: 1959-1969.

73. Hamlet CG, Sadd PA, Liang L (2008) Correlations between the amounts of free asparagine and saccharides present in commercial cereal flours in the UK and the generation of acrylamide during cooking. Journal of Agriculture and Food Chemistry 56: 6145-6153.

74. Weisshaar R (2004) Acrylamide in bakery products- Results from mode experiments. Deutsche Lebensm. Rundschau 100: 92.

75. Noti A, Biedermann BS, Biedermann M, Grob K, Albisser P, et al. (2003) Storage of potatoes atlow temperature should be avoided to prevent increased acrylamide formation during frying or roasting. Mitt. Lebensm Hyg 94: 167-180.

76. De Wilde T, Meulenaer DB, Mestdagh F, Verhé R, Govaert Y, et al. (2004) Acrylamide formation during frying of potatoes: Thorough investigation on the influence of crop and process variables. Czech Journal of Food Science 22 $15-18$.

77. Sanny M, Jinap S, Bakker EJ, Van BMAJS, Luning PA (2012) Is lowering reducing sugars concentration in French fries an effective measure to reduce acrylamide concentration in food service establishments. Food Chemistry 135 2012-2020.

78. Amrein TM, Bachman S, Noti A, Biedermann M, Barbosa MF, et al. (2003) Potential of acrylamide formation, sugars and free asparagine in potatoes: a comparison of cultivars and farming systems. Journal of Agricultural and Food Chemistry 51: 5556-5560.

79. Amrein TM, Schönbächler B, Escher F, Amadó R (2004) Acrylamide in gingerbread: critical factors for formation and possible ways for reduction. Journal of Agricultural and Food Chemistry 52: 4282-4288.

80. Stadler RH (2006) The formation of acrylamide in cereal products and coffee Acrylamide and Other Hazardous Compounds in Heat-treated Foods. Wood head Publishing, Cambridge.

81. Claus A, Carle R, Schieber A (2008) Acrylamide in cereal products: A review. J Cereal Sci 47: 118-133.

82. Claus A, Mongili M, Weisz G, Schieber A, and Carle R (2008) Impact of formulation and technological factors on the acrylamide content of wheat bread and bread rolls. Journal of Cereal Science 47: 546-554.

83. Umano K, Shibamoto T (1987) Analysis of acrolein from heated cooking oils and beef fat. Journal of Agriculture and Food Chemistry 35: 909-912.

84. Gertz C, Klostermann S (2002) Analysis of acrylamide and mechanisms of its formation in deep-fried foods. Eur J Lipid Sci Technol 104: 762-771.

85. Becalski A, Lau BPY, Lewis D, Seaman SW, Hayward S, et al. (2004) Acrylamide in French fries: Influence of free amino acids and sugars. J Agric Food Chem 52: 3801-3806.

86. Stadler RH, Verzegnassi L, Varga N, Grigorov M, Studer A, et al. (2003) Formation of vinylogous compounds in model Maillard reaction systems. Chem Res Toxicol 16: 1242-1250.

87. Yaylayan VA, Perez LC, Wnorowski A, Brien OJ (2004) The role of creatine in the generation of $\mathrm{N}$-methyl acrylamide: a new toxicant in cooked meat. Journal of Agricultural and Food Chemistry 52: 5559-5565

88. Hidalgo FJ, Zamora R (2007) Conversion of phenylalanine into styrene by 2 4-decadienal in model systems. Journal of Agriculture and Food Chemistry 55: 4902-4906.

89. Zamora R, Gallardo E, Hidalgo FJ (2007) Strecker degradation initiated by 2, 4-decadienal or methyl 13-oxooctadeca-9, 11-dienoate in model systems. Journal of Agriculture and Food Chemistry 55: 1308-1314.

90. Sohn M, Ho CT (1995) Ammonia generation during thermal degradation of amino acids. Journal of Agricultural and Food Chemistry 43: 3001-3003.

91. Ezeji T, Groberg M, Qureshi N, Blaschek H (2003) Continuous production of butanol from starch-based packing peanuts. Applied Biochemistry and Biotechnology 106: 375-382.

92. Vass M, Amrein TM, Schönbächler B, Escher F, Amadó R (2004) Ways to 
reduce acrylamide formation in cracker products. Czech Journal of Food Science 22: 19-21.

93. Biedermann M, Grob K, Gutsche B, Weisshaar R (2003) Heated foods: The component eluated next to acrylamide is 2-pyrrolidinone, not 3-Buteneamide. Deutsche Lebensmittel-Rundschau 99: 171-175.

94. De Wilde T, De Meulenaer B, Mestdagh F, Govaert Y, Vandeburie S, et al (2005) Influence of storage practices on acrylamide formation during potato frying. Journal of Agricultural and Food Chemistry 53: 6550-6557.

95. De Wilde T, De Meulenaer B, Mestdagh F, Govaert Y, Ooghe W, et al. (2006a) Selection criteria for potato tubers to minimize acrylamide formation during frying. Journal of Agricultural and Food Chemistry 54: 2199-2205.

96. De Wilde T, De Meulenaer B, Mestdagh F, Govaert Y, Vandeburie S, Ooghe $W$, et al. (2006) Influence of fertilization on acrylamide formation during frying of potatoes harvested in 2003. Journal of Agricultural and Food Chemistry 54: 404-408.

97. Truong VD, Pascua Y, Reynolds R (2013) Processing Treatments for Reducing the Acrylamide Level in Sweet potato French Fries. Journal of agricultural and food chemistry 62 : 310-316

98. Haase NU, Matthaus B, Vosmann K (2004) Aspects of acrylamide formation in potato crisps. J Appl Bot Food Qual 78: 144-147.

99. Springer M, Fischer T, Lehrack A, Freund W (2003) Acrilamidbildung in backwaren. Development of acrylamide in baked products. Getreide MehlBrot 57: $274-278$

100. Taeymans D, Wood J, Ashby P, Blank I, Studer A, et al. (2004) A review of acrylamide: an industry perspective on research, analysis, formation, and control. Critical Reviews in Food Science and Nutrition 44: 323-347.

101. Claus A, Schreiter P, Weber A, Graeff S, Hermann W, et al. (2006b) Influence of agronomic factors and extraction rate on the acrylamide contents in yeastleavened breads. Journal of Agricultural and Food Chemistry 54: 8968-8976.

102. Muttucumaru N, Elmore JS, Curtis T, Mottram DS, Parry MAJ, et al. (2008) Reducing Acrylamide Precursors in Raw Materials Derived from Wheat and Potato. J Agric Food Chem 56: 6167-6172.

103. Torres MDA, Parreño WC (2009) Thermal processing and quality optimization Advances in potato chemistry and technology.

104. Fiselier K, Grob K (2005) Legal limit for reducing sugars in prefabricates targeting $50 \mu \mathrm{g} / \mathrm{kg}$ acrylamide in French fries. Eur Food Res Technol 220: 451-458.

105. Lindsay RC, Jang SJ (2005) Chemical intervention strategies for substantia suppression of acrylamide formation in fried potato products. Chemistry and safety of acrylamide in food 561: 393-404.

106. Park YW, Yang HW, Storkson JM, Albright KJ, Liu W, et al. (2005) Controlling acrylamide in French fry and potato chip models and a glucose model system by RP-HPLC-DAD. Journal of the Science of Food and Agriculture 89: 6741681.

107. Mestdagh F, Maertens J, Cucu T, Delporte K, Van Peteghem C, et al. (2008c) Impact of additives to lower the formation of acrylamide in a potato model system through $\mathrm{pH}$ reduction and other mechanisms. Food Chemistry 107: 26-31.

108. Blenkinsop RW, Copp LJ, Yada RY, Marangoni AG (2002) Changes in compositional parameters of tubers of potato (Solanum tuberosum) during low temperature storage and their relationship to chip processing quality. Journal of Agricultural and Food Chemistry 50: 4545-4553.

109. Viklund G, Olsson K, Sjöholm I, Skog K (2008) Variety and storage conditions affect the precursor content and amount of acrylamide in potato crisps. Journal of the Science of Food and Agriculture 88: 305-312.

110. Viklund G, Olsson K, Sjoholm I, Skog K (2010) Acrylamide in crisps: Effect of blanching studied on long-term stored potato clones. Journal of Food Composition and Analysis 23: 194-198.

111. Knutsen SH, Dimitrijevic S, Molteberg EL, Segtnan VH, Kaaber L, et al. (2009) The influence of variety, agronomical factors and storage on the potential for acrylamide formation in potatoes grown in Norway. LWT- Food Science and Technology 42: 550-556.

112. Biedermann $M$, Biedermann BS, Noti A, Grob K, Egli $P$, et al (2002a) Two GC-MS methods for the analysis of acrylamide in foods. MitteilungenausLebensmitteluntersuchungund Hygiene 93: 638-652.
113. Biedermann M, Noti A, Biedermann-Brem S, Mozzetti V, Grob K (2002b) Experiments on acrylamide formation and possibilities to decrease the potential of acrylamide formation in potatoes. MitteilungenausLebensmitteluntersuchung und Hygiene 93: 668-687.

114. De Wilde T, De Meulenaer B, Mestdagh F, Verhé R, Govaert Y, et al. (2002) Acrylamide formation during frying of potatoes: thorough investigation on the influence of crop and process variables. In Proceedings Chemical Reactions in Food 4: 15-18.

115. CIAA (2009) Rev 12. The CIAA acrylamide toolbox. Confederation of the European Food and Drink Industries (CIAA), Brussels.

116. Ciesarová Z, Kiss E, Boegl P (2006) Impact of L-asparaginase on acrylamide content in potato product. J Food Nutr Res 45: 141-146.

117. Kumar D, Singh BP, Kumar P (2004) An overview of the factors affecting sugar content of potatoes. Annals of Applied Biology 145: 247-256.

118. Pedreschi F, Kaack K, Granby K (2008) The effect of asparaginase on acrylamide formation in French fries. Food Chemistry 109: 386-392.

119. Hendriksen HV, Kornbrust BA, Oestergaard R, Stringer MA (2009) Evaluating the potential for enzymatic acrylamide mitigation in a range of food products using an asparaginase from Aspergillus oryzae. J Agric Food Chem 57: 41684176 .

120. Medeiros VR, Mestdagh F, De Muer N, Van PC, Meulenaer DB (2010) Effective quality control of incoming potatoes as an acrylamide mitigation strategy for the French fries industry. Food Additives and Contaminants: Part A. Chemistry Analysis Control Exposure and Risk Assessment 27: 417-425.

121.Pedreschi F, Mariotti S, Granby K, Risum J (2011) Acrylamide reduction in potato chips by using commercial asparaginase in combination with conventional blanching. LWT-Food Sci Technol 44: 1473-1476.

122. Rydberg P, Eriksson S, Tareke E, Karlsson P, Ehrenberg L, et al. (2003) Investigations of factors that influence the acrylamide content of heated foodstuffs. Journal of Agricultural and Food Chemistry 51: 7012-7018.

123. Vattem DA, Shetty K (2005) Composition of legume proteins and methods of use thereof for reducing acrylamide in cooked foods. Patent US20050048172.

124. Brathen E, Knutsen SH (2005) Effect of temperature and time on the formation of acrylamide in starch based and cereal model systems, flat breads and bread. Food Chem 92: 693-700.

125. Claeys W, De Vleeschouwer K, Hendrickx ME (2005) Kinetics of acrylamide formation and elimination during heating of an asparagine-sugar mode system. Journal of Agricultural and Food Chemistry 53: 9999-10005.

126. Claeys W, De Vleeschouwer K, Hendrickx ME (2005) Effect of amino acids on acrylamide formation and elimination kinetics. Biotechnology Progress 21 : 1525-1530.

127. Hanley AB, Offen C, Clarke M, Ing B, Roberts M, et al. (2005) Acrylamide reduction in processed foods. Chemistry and safety of acrylamide in food 561 : 387-392.

128. Kim CT, Hwang ES, Lee HJ (2005) Reducing Acrylamide in Fried Snack Products by Adding Amino Acids. Food Chem Toxicol 70: 354-358.

129. Fink M, Andersson R, Rosen J, Aman P (2006) Effect of added asparagine and glycine on acrylamide content in yeast leavened bread. Cereal Chemistry 83: $218-222$.

130.Low MY, Koutsidis G, Parker JK, Elmore JS, Dodson AT, Mottram DS (2006) Effect of citric acid and glycine addition on acrylamide and flavor in a potato model system. Journal of Agricultural and Food Chemistry 54: 5976-5983.

131. Mestdagh F, De Wilde T, Fraselle S, Govaert Y, Ooghe W, et al. (2008) Optimization of the blanching process to reduce acrylamide in fried potatoes. LWT- Food Sci Technol 41:1648-54.

132. Mestdagh F, Castelein P, et al. (2008) Importance of oil degradation components in the formation of acrylamide in fried foodstuffs. J Agric Food Chem 56: 6141-6144.

133. Ou SY, Lin Q, Zhang YP, Huang CH, Sun X, Fu L (2008) Reduction of acrylamide formation by selected agents in fried potato crisps on industrial scale. Innovative Food Science and Emerging Technologies 9: 116-121.

134. Anese M, Suman M, Nicoli MC (2009) Technological Strategies to Reduce Acrylamide Levels in Heated Foods. Food Eng Rev 1: 169-179. 
135. Levine RA, Smith RE (2005) Sources of variability of acrylamide levels in a cracker model. J Agric Food Chem 53: 4410-4416

136. Elder VA (2005) Method for enhancing acrylamide decomposition. Paten US20050118322.

137. Flückiger R, Salih E (2006) Method to limit acrylamide in heated foods. Patent WO2006017526.

138. Fernandez S, Kurppa L, Hyvönen L (2003) Content of acrylamide decreased in potato chips with addition of a proprietary flavonoid spice mix (Flavomare) in frying. Innovations in Food Technology 18: 24-26.

139. Tareke E (2003) Identification and origin of potential background carcinogens: Endogenous isoprene and oxiranes, dietary acrylamide. Doctoral thesis, Department of Environmental Chemistry, Stockholm University, Sweden.

140. Summa C, Wenzl T, Brohee M, de la Calle B, Anklam E (2006) Investigation of the correlation of the acrylamide content and the antioxidant activity of model cookies. J Agric Food Chem 54: 853-859.

141.Zhang Y, Chen J, Zhang X, Wu X, Zhang Y (2007) Addition of antioxidant of bamboo leaves (AOB) effectively reduces acrylamide formation in potato crisps and French fries. Journal of Agricultural and Food Chemistry 55: 523 528.

142. Hedegaard RV, Granby K, Frandsen H, Thygesen J, Skibsted LH (2008) Acrylamide in bread: Effect of prooxidants and antioxidants. European Food Research and Technology 227: 519-525.

143. Zhu F, Cai YZ, Ke JX, Corke H (2009) Evaluation of the effect of plant extracts and phenolic compounds on reduction of acrylamide in an asparagine/ glucose model system by RP-HPLC-DAD. Journal of the Science of Food and Agriculture 89: 1674-1681.

144.Zhu F, Cai YZ, Ke J, Corke H (2010) Compositions of phenolic compounds amino acids and reducing sugars in commercial potato varieties and their effects on acrylamide formation. Journal of the Science of Food and Agriculture 90: 2254-2262.

145. Ou SY, Shi JJ, Huang CH, Zhang GW, Teng JW, et al. (2010) Effect of antioxidants on elimination and formation of acrylamide in model reaction systems. Journal of Hazardous Materials 182: 863-868.

146.Zhang Y, Zhang G, Zhang Y (2005) Occurrence and analytical methods of acrylamide in heat-treated foods: Review and recent developments. Journal of Chromatography A 1075: 1-21.

147.Zhang Y, Zhang Y (2008) Effect of natural antioxidants on kinetic behaviour of acrylamide formation and elimination in low-moisture asparagine-glucose model system. Journal of Food Engineering 85: 105-115.

148. Totlani VM, Peterson DG (2006) Epicatechin carbonyl-trapping reactions in aqueous Maillard systems: identification and structural elucidation. J Agric Food Chem 54: 7311-7318.

149. Granby K, Nielsen NJ, Hedegaard RV, Christensen T, Kann M, et al. (2008) Acrylamide-asparagine relationship in baked/toasted wheat and rye breads. Food Addit Contam Part A 25: 921-929.

150.Elder VA, Fulcher JG, Leung H, Topor MG (2004) Method for reducing acrylamide in thermally processed foods. Patent US20040058045.

151. Tomoda Y, Hanaoka A, Yasuda T, Takayama T, Hiwatashi A (2004) Preparing food to be cooked by heat treatment and removing polyvalent cations by flushing with water. US Patent Application 20040126469.

152. Levine RA, Ryan SM (2009) Determining the effect of calcium cations on acrylamide formation in cooked wheat products using a model system. Journal of Agricultural and Food Chemistry 57: 6823-6829.

153. Pedreschi F, Granby K, Risum J (2010) Acrylamide mitigation in potato chips by using $\mathrm{NaCl}$. Food and Bioprocess Technology 3: 917-921.

154. Kolek E, Simko P, Simon P (2006) Effect of $\mathrm{NaCl}$ on the decrease of acrylamide content in a heat-treated model food matrix. Journal of Food and Nutrition Research 45: 17-20.

155. Gokmen V, Senyuva HZ (2007) Acrylamide formation is prevented by divalent cations during the Maillard reaction. Food Chem 103: 196-203.

156. Voelker L (2005) Interactions of baker's yeast with dough substances. Getreidetechnologie 59: 10-14.

157.Zeng XH, Cheng KW, Du YG, Kong R, Lo C, Chu IK, et al. (2010) Activities of hydrocolloids as inhibitors of acrylamide formation in model systems and fried potato strips. Food Chemistry 121: 424-428.

158. Elmore JS, Koutsidis G, Dodson AT, Mottram DS, et al. (2005) Measurement of acrylamide and its precursors in potato, wheat, and rye model systems. $J$ Agric Food Chem 53: 1286-1293.

159. Mustafa A, Andersson R, Rosen J, Kamal EA, Aman P (2005) Factors influencing acrylamide content and color in rye crisp bread. Journal of Agricultural and Food Chemistry 53: 5985-5989.

160. Ahrné L, Andersson CG, Floberg P, Rosén J, Lingnert H (2007) Effect of crus temperature and water content on acrylamide formation during baking of white bread: Steam and falling temperature baking. LWT Food Sci. Technol 40: 1708-1715.

161.Lukac H, Amrein TM, Perren $\mathrm{R}$, Petit $\mathrm{BC}$, Amado $\mathrm{R}$, et al. (2007) Influence of roasting conditions on the acrylamide content and the color of roasted almonds. Food Chem Toxicol 72: 33-38.

162. HEATOX (2007) HEATOX: Heat-generated food toxicants: Identification, characterisation and risk minimisation. Lund, Sweden: Lund University.

163. Anese M, Suman M, Nicoli MC (2010) Acrylamide removal from heated foods Food Chemistry 119: 791-794

164. Vleeschouwer K, Van der PI, Van LA, Hendrickx ME (2007) Kinetics of Acrylamide formation/elimination reactions as affected by water activity. Biotechnol Progr 23: 722-728.

165. Sadd PA, Hamlet GH, Liang L (2008) Effectiveness of methods for reducing acrylamide in bakery products. Journal of Agricultural and Food Chemistry 56: 6154-6161.

166. Sadd P, Hamlet C (2005) The formation of acrylamide in UK cereal products Chemistry and Safety of Acrylamide in Foods 561: 415-429.

167.Pedreschi F, Kaack K, Granby K (2004) Reduction of acrylamide formation in potato slices during frying. LWT-Food Science and Technol 37: 679-685

168. Pedreschi F, Moyano PC (2005) Effect of pre drying on texture and oil uptake of potato chips. LWT-Food Sci Technol 38: 599-604.

169.Pedreschi F, Travisany X, Reyes C, Troncoso E, Pedreschi R (2009) Kinetics of extraction of reducing sugar during blanching of potato slices. Journal of Food Engineering 91: 443-447.

170. Mestdagh F, De Wilde T, Fraselle S, Govaert Y, Ooghe W, et al. (2008d) Optimization of the blanching process to reduce acrylamide in fried potatoes. LWT- Food Science and Technology 41: 1648-1654.

171.Viklund G, Mendoza F, Sjöholm I, Skog K (2007) An experimental set up for studying acrylamide formation in potato crisps. LWT-Food Science and Technology 40: 1066-1071.

172. Samir A, Rehab F, Mohsen A, Wafaa M (2013) Impacts of pre-treatments on the acrylamide formation and organoleptic evaluation of fried potato chips. American Journal of Biochemistry and Biotechnology 9: 90-101.

173. Fiselier K, Bazzocco D, Gama-Baumgartner F, Grob K (2006) Influence of the frying temperature on acrylamide formation in French fries. Eur. Food Res Techno 222: 414-419.

174. Amrein TM, Andres L, Escher F, Amado R (2007) Occurrence of acrylamide in selected foods and mitigation options. Food Additives and Contaminants 24: $13-25$.

175. Granda C, Moreira RG, Tichy SE (2004) Reduction of Acrylamide Formation in Potato Chips by Low temperature Vacuum Frying. J Food Sci 69: 405-411.

176. Grob K (2007) Options for legal measures to reduce acrylamide contents in the most relevant foods. Food Additives and Contaminants 24: 71-81.

177. Jung MY, Choi DS, Ju JW (2003) A novel technique for limitation of acrylamide formation in fried and baked corn chips and in French fries. J Food Sci 68: $1287-1290$.

178. Graf M, Amrein TM, Graf S, Szalay R, Escher F, et al. (2006) Reducing the acrylamide content of a semi-finished biscuit on industrial scale. LWT- Food Science and Technology 39: 724-728.

179. Mottram DS, Wedzicha BL, Dodson AT (2002) Acrylamide is formed in the Maillard reaction. Nature 419: 448-449.

180. Delatour T, Perisset A, Goldmann T, Riediker S, Stadler R (2004) Improved sample preparation to determineacrylamide in difficult matrixes such as 
Citation: Krishnakumar T, Visvanathan R (2014) Acrylamide in Food Products: A Review. J Food Process Technol 5: 344. doi:10.4172/21577110.1000344

chocolate powder, cocoa, and coffee by liquid chromatographytandem mass spectroscopy. J Agric Food Chem 52: 4625-4631.

181. Hoenicke K, Gatermann R (2004) Stability of acrylamide in food during storage. Czech Journal of Food Science 22: 355-356.

182. Hoenicke K, Gatermann R (2005) Studies on the stability of acrylamide in food during storage. Journal of AOAC International 88: 268-273.

183. Fredriksson H, Tallving J, Rosen J, Aman P (2004) Fermentation reduces free asparagine in dough and acrylamide content in bread. Cereal Chem 81: 650653.
184. Konings EJM, Ashby P, Hamlet CG, Thompson GAK (2007) Acrylamide in cereal and cereal products: a review on progress in level reduction. Food Addit Contam 24: 47-59.

185. Sadd PA, Hamlet GH, Liang L (2008) Effectiveness of methods for reducing acrylamide in bakery products. Journal of Agricultural and Food Chemistry 56: 6154-6161.

186. FDE (2011)Food Drink Europe Acrylamide Toolbox.

187. Baardseth P, Blom H, Skrede G, Mydland LT, Skrede A (2006) Lactic acid fermentation reduces acrylamide formation and other Maillard reactions in French fries. Journal of Food Science 71: C28-C33. 